\title{
'We Are a Global Community': Communicating Knowledge through Moocs and Teacher Training Platforms
}

\author{
Michela Giordano (Corresponding author) \\ Department of Humanities, Languages and Heritage, University of Cagliari, Italy \\ Email: mgiordano@unica.it \\ Maria Antonietta Marongiu ${ }^{1}$ \\ Faculty of Economic, Law and Political Sciences, University of Cagliari, Italy
}

Received: 25/06/2021

Accepted: 07/09/2021

Published: 01/11/2021

Volume: 2 Issue: 6

How to cite this paper: Giordano, M., \& Marongiu, M. A. (2021). 'We Are a Global Community': Communicating Knowledge through Moocs and Teacher Training Platforms. Journal of Critical Studies in Language and Literature, 2(6), 38-51

DOI: https://doi.org/10.46809/jcsll.v2i6.123

Copyright (C) by author(s) and Global Talent Academy Ltd. This work is licensed under the Creative Commons Attribution International License (CC BY 4.0). http://creativecommons.org/licenses/by/4.0/

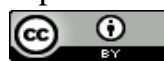

\begin{abstract}
A socio-rhetorical discourse community consists of a group of people who come together to pursue objectives that predate those of socialization and solidarity, and who aim to develop and maintain their own discoursal characteristics. We have examined MOOCs (Massive Open Online courses) and teacher training educational platforms in order to ascertain whether and to what extent they may be identified as networked learning tools and discourse communities characterized by a commonality of goals, mechanisms and procedures of intercommunication, exchange of knowledge, information, as well as specialized genres and their terminology. MOOCs and learning platforms have dramatically changed the way people learn. Starting from ongoing research, we analyze the metadiscoursal features of an ad hoc corpus of online filmed lectures drawn from two MOOC providers (FutureLearn and Coursera). We look at both interactive and interactional resources (to guide the listener through the texts and to involve the listener in the subject), in order to discover how these features are used to control, evaluate and negotiate the communicative goals and impact of the ongoing exchanges. The quantitative and qualitative analysis shows a significant use of metadiscourse markers in the video lectures with a higher frequency of interactional features such as self-mentions, engagement markers, hedges and boosters, rather than interactive ones. These commentaries in the lectures signal the instructors' attitudes towards the texts and their listeners. Additionally, they were found to perform a rhetorical function since they persuasively reinforce the instructors' attitude and stance. Thus, their use engages the participants as members of a digital community, where commitment, dedication, and common goals seem to be fundamental features.
\end{abstract}

Keywords: Metadiscourse, MOOCs, Online Learning Platforms, Discourse Communities, Teacher Training

\section{Introduction}

As Pouezevara \& Horn have argued (2016, p. 1), the spread in the use of technology, among the other things, "[ [...] has also changed the way education is delivered. The growth in massive open online courses (MOOCs) is one example of howtechnology is transforming education and training delivery [...]". 
Metadiscourse in video lessons in online teachers' courses and MOOCs is the topic of the present study, which is part of ongoing research started in 2019 with the work "And as I said at the beginning, this is a journey in which we are embarking: Metadiscourse as rhetorical strategy in online teaching methodology courses" presented at "Metadiscourse in Digital Communication: What has changed?", an International Conference hosted by CERLIS, University of Bergamo, Italy. The work was published in the volume Digital Communication and Metadiscourse. Changing Perspectives in Academic Genres (Consonni, D’Angelo \& Anesa, eds.) in 2020.

Some of the data analysed in the 2020 paper is also used here to compare the results with new data gathered from other sources. Our 2020 paper considered two MOOCs taken from the FutureLearn platform, while the new added data was gathered from two teacher training courses in the Coursera platform. Data will be further described in detail in Section 3, Materials and Methods.

Instructors in online teaching methodology courses use a vast array of metadiscourse features in the form of commentaries embedded in the oral texts, which express the speakers' intentions towards the text itself and the listeners. The research objective of this study was to find out whether the metadiscourse features found in written discourse are also used in spoken discourse, through the analysis of video lessons in MOOC courses for teachers. It endeavoured to discover whether metadiscursive elements can be interpreted as signs of the speakers'/instructors' attitudes towards the content and their audience, and finally whether they can be deemed as rhetorical and persuasive within a specific discourse community, i.e. that of the teaching profession and would-be teachers. Therefore, one of the research questions is whether metadiscursive features contribute to the persuasive impact of methodological lessons taught online.

The study also looks at the importance of socialization, which seems to be a fundamental part of MOOC courses, given that knowledge is socially constructed, developed and reinforced among the learners themselves, together with the instructors and the community with whom they are interacting. Therefore, the concept of discourse community is considered as long as MOOCs represent an opportunity to share materials, procedures and content in order to enhance knowledge together with interactivity and expertise.

\section{Theoretical Framework}

\subsection{Metadiscourse}

The interpretation of metadiscourse is highly context-dependent and this is one of the reasons why researchers have disagreed on its definition and on the methodology required to study it. This term has been used in speech communication studies since the 1950s, yet it gained greater relevance in the 1980s, when investigations focused especially on the study of written texts. Studies on metadiscourse have taken into consideration school textbooks (Crismore, 1989), company annual reports (Hyland, 1998b), and especially academic texts, such as undergraduate textbooks (Hyland, 2000), postgraduate dissertations (Hyland \& Tze, 2004; Swales, 1990), and research articles from a variety of disciplines (Hyland, 1998a).

Few researchers have looked into spoken text genres, such as academic lectures (Ädel, 2012) and digitalised discourse (Ryoo Mi-Lim, 2005). Studies have especially concentrated on texts produced in English by native or non-native speakers (Mauranen, 1993), yet some attention has also been devoted to metadiscourse in text production in other languages. Vande Kopple (1985, p. 87) defined metadiscourse as "communication about communication" and identified two distinguished processing levels in text writing: one to provide propositional content, and the other, that of metadiscourse, where the writer organises discourse in order to help readers relate to the matter at hand. Vande Kopple classified metadiscourse in textual categories (text connectives, code glosses, illocution markers, and narrators) and interpersonal categories (validity markers, attitude markers, and commentary). Crismore (1989) initially classified metadiscourse in written texts as informational and attitudinal, and later adopted the distinction between textual and interpersonal metadiscourse (Crismore et al., 1993). Ädel (2006) developed a taxonomy of metadiscourse based on the concept of Jakobson's notion of text reflexivity. Ädel's strictly context-related perspective has been applied to the analysis of metadiscourse in spoken and written academic English (Ädel, 2010 and 2012).

In his taxonomy, Hyland (2005) distinguished between interactive and interactional metadiscourse. Among the interactive strategies, with which the writer guides readers' interpretation of propositional information, he listed transition markers, frame markers, endophoric markers, evidentials, and code glosses. In the category of interactional strategies, defined as the writer's own stance towards the content matter and the intended reader, he catalogued hedges, boosters, attitude markers, self mentions and engagement markers. In his extended studies on metadiscourse in a variety of text genres, Hyland (1998a, 2000, 2005, 2017) and Hyland \& Feng (2018) have insisted on the articulated role of metadiscourse as the writers' goals are often multi-layered. The use of metadiscourse is meant to assist readers to appropriately contextualise a text, and to interpret it according to the values of a specific discourse community. In point of fact, the concept of discourse community is the starting point for the present study. The writer's or speaker's final aim is to make a text "coherent, intelligible and persuasive to a particular audience" (Hyland \& Tse, 2004, in Hyland, 2017, p. 18). Hence, metadiscourse is strictly context-related and may change across text genres and languages; moreover, the same function may perform additional metadiscoursal functions in the same or in different texts.

\subsection{MOOCs as Discourse Communities}

As stated in the Introduction, this analysis considers MOOC courses as a type of discourse community, since they seem to possess all the six defining characteristics identified by Swales (1990, pp. 24-27). A discourse community: 
1) has a broadly agreed set of common public goals;

2) has mechanisms of intercommunication among its members;

3) uses its participatory mechanisms primarily to provide information and feedback;

4) utilizes and hence possesses one or more genres in the communicative furtherance of its aims;

5) has acquired some specific lexis;

6) has a threshold of members with a suitable degree of relevant content and discoursal expertise.

Barab, Makinster, Moore \& Cunningham in 2001, citing Lave \& Wenger (1991), used the term communities of practice to indicate "the importance of activity in binding individuals to communities, and in communities legitimizing and developing individual practices" (2001, p. 76). The authors also argue that "[ $\mathrm{t}]$ he shared experiences of a community come to constitute a collective repertoire of activities and means of participation (that can include knowledge) that is continually negotiated anew through each interaction" (2001, p. 76). Based on this assumption, the interactive nature of the video lectures in the MOOCs under scrutiny is the object of this study. As members of a discourse community, MOOCs providers and addressees, "actively share goals and communicate with other members to pursue those goals" (Borg 2003, p. 398).

Clearly, technology has made participation in discourse communities easier (Kim \& Vorobel, 2015), favouring the increase in the number of community members. Accordingly, research has begun to explore how technology-mediated discourse communities form, change and work. Pouezevara \& Horn (2016, p. 4) explain that MOOCs share two of the main features of online learning, "the location and temporal independence of learning, often referred to as "anytime, anywhere", and "( $\mathrm{t}$ )he ability to reach a diverse population of learners" which can be considered as "a valuable pedagogical strategy in addition to building communities and favouring follow-on action". These aspects are particularly relevant when dealing with MOOCs and teacher training platforms.

As regards studies in metadiscursive elements in MOOCs, this paper takes into consideration the work by Bernard-Mechó (2015, pp. 61-62), who stresses that "although most research on metadiscourse has revolved around written language, there are an increasing number of studies whose focus is spoken academic discourse". The author focuses in particular on the relationship between linguistic and paralinguistic elements in a series of video lectures about African American History. Starting from a multimodal perspective, he concludes that further research is needed since metadiscourse and non-verbal aspects have traditionally been neglected in this research field, notwithstanding the fact that they are of "undeniable importance" (2015, p. 66).

A very recent paper by Zhang and Sheng (2021) analyses metadiscourse in EFL lecturers' belonging to Chinese university MOOCs. Findings suggest that the specific educational context in MOOCs reveals a low frequency of metadiscourse features and their use mainly serves to enhance intelligibility, reliability and interactivity. The authors explain that MOOCs were the subject of much attention at the beginning of 2020 in China because of the outbreak of Covid-19 and they argue that they have the "advantage of liberating education from geographical restriction" (2021, p. 244). The three factors of intelligibility, reliability and interactivity will be also investigated in the corpus under scrutiny in this work. Metadiscursive features will be analysed in context to understand how they work in technology-based training courses for teachers. In particular, our attention will focus on video lectures, which combine the logical relationship of arguments and disciplinary knowledge with discussions on teaching methodologies, objectives and content.

\section{Materials And Methods}

"MOOCs can be defined in many different ways. For example, "massive" can be interpreted as a course delivered to a large number of learners who interact simultaneously in the same class", while "open" typically means free of fees and entry requirements" (Pouezevara \& Horn, 2016, p. 2). Singh \& Chauhan (2017) explain how MOOCs are a relatively recent phenomenon. The term was first used by Stephen Downes and George Siemens in 2008 at the University of Prince Edward Island (UPEI) for a course about Connectivism and Connective Knowledge (CCK08), and since then over $4000 \mathrm{MOOCs}$ are available worldwide and have 35 million registered users (2017, pp. 81-82).

We looked at four MOOCs in this study. The first sub-corpus comprises two courses, "Teaching Your Subject in English" and "Teaching English Online", both produced by the University of Cambridge and powered by FutureLearn, which is a digital education platform founded in December 2012. It is a learning platform which provides online courses aimed at open participation and access via the web. In addition to traditional course materials which are presented through a variety of genres such as filmed lectures, readings, quizzes and assignments, many MOOCs provide interaction through user forums to support community exchanges among students, professors, and teaching assistants.

The second sub-corpus comes from the platform Coursera, an American MOOC provider founded in 2012 by Stanford University. Like FutureLearn, Coursera works with universities and other organizations to offer online courses, certifications, and degrees in a variety of subjects. Additionally, similarly to FutureLearn, Coursera courses last anywhere from four to twelve weeks, with one or two hours of video lectures per week. Both platforms provide weekly exercises, quizzes, peergraded and peer-reviewed assignments, and a final project or final exam to complete the course. The courses in this second sub-corpus are "Teach English Now! Theories of Second Language Acquisition" and "Teach English Now! Lesson Design and Assessment", both offered by Arizona State University as part of an online program for the fulfilment of the requirements for the TESOL Professional Certificate. 
Along with the several genres employed in the MOOC courses, the discourse community is gradually built up and continues to develop discoursal expectations. As Swales notes, "these discoursal expectations are created by the genres that articulate the operations of the discourse community" (1990, p. 26). The genre under investigation here is the filmed lecture or video lesson, which forms a significant part of all courses in the corpus.

As can be seen from Table 1, the "Teaching Your Subject in English" course starts with a Welcome week followed by five weeks of study. The duration of each video lesson is also indicated along with the total number of videos (23), totalling one hour and ten minutes of talking, adding up to 11,988 words in the transcripts.

Table 1. Teaching Your Subject in English MOOC Course from FutureLearn

\begin{tabular}{|l|c|c|c|}
\hline \multicolumn{4}{|c|}{ Teaching Your Subject in English } \\
\hline Section & Videos & Duration & \# of words \\
\hline Welcome to the course & 1 video & $00: 00: 52$ & 236 \\
\hline Week 1 & 6 videos & $00: 20: 23$ & 3059 \\
\hline Week 2 & 4 videos & $00: 12: 29$ & 2064 \\
\hline Week 3 & 4 videos & $00: 10: 19$ & 1783 \\
\hline Week 4 & 4 videos & $00: 12: 07$ & 2194 \\
\hline Week 5 & 4 videos & $00: 14: 33$ & 2652 \\
\hline Grand totals & 23 videos & $01: 10: 43$ & 11,988 \\
\hline \multirow{2}{*}{} & & Tokens & 13,896 \\
\cline { 3 - 4 } & & Sentences & 766 \\
\hline
\end{tabular}

The "Teaching English Online" course (Table 2) begins with a Welcome video plus four weeks of activities that include 35 video lessons. The total duration amounts to one hour and thirty-three minutes, making a total of 15,670 words in the video transcripts.

Table 2. Teaching English Online MOOC Course from FutureLearn

\begin{tabular}{|l|c|c|c|}
\hline \multicolumn{4}{|c|}{ Teaching English Online } \\
\hline Section & Videos & Duration & \# of words \\
\hline Welcome to the course & 1 video & $00: 01: 15$ & 332 \\
\hline Week 1 & 10 videos & $00: 27: 03$ & 4852 \\
\hline Week 2 & 7 videos & $00: 13: 08$ & 2416 \\
\hline Week 3 & 11 videos & $00: 36: 11$ & 5019 \\
\hline Week 4 & 7 videos & $00: 16: 06$ & 3051 \\
\hline Grand totals & 35 videos & $01: 33: 43$ & 15,670 \\
\hline & & Tokens & 18,776 \\
\cline { 2 - 4 } & & Sentences & 1,457 \\
\hline
\end{tabular}

Taking into consideration the sub-corpus drawn from the Coursera platform, the "Theories of Second Language Acquisition" course has a Welcome week followed by six weeks of study, and a total of 35 video lessons. Table 3 shows the total duration of the course, which lasts for three hours and fourteen minutes. The transcripts amount to 24,947 words.

Table 3. Theories of Second Language Acquisition MOOC Course from Coursera

\begin{tabular}{|l|c|c|c|}
\hline \multicolumn{4}{|c|}{ Theories of Second Language Acquisition } \\
\hline Section & Videos & Duration & \# of words \\
\hline Welcome to the course & 1 video & $00: 02: 00$ & 271 \\
\hline Week 1 & 5 videos & $00: 19: 00$ & 2583 \\
\hline Week 2 & 7 videos & $00: 37: 00$ & 4700 \\
\hline Week 3 & 7 videos & $00: 39: 00$ & 5072 \\
\hline Week 4 & 7 videos & $00: 40: 00$ & 4967 \\
\hline Week 5 & 7 videos & $00: 45: 00$ & 5842 \\
\hline
\end{tabular}




\begin{tabular}{|l|c|c|c|}
\hline Week 6 & 1 video & $00: 12: 00$ & 1512 \\
\hline Grand totals & 35 videos & $03: 14: 00$ & 24,947 \\
\hline \multirow{2}{*}{} & Tokens & 28,917 \\
\cline { 2 - 4 } & & Sentences & 1,684 \\
\cline { 3 - 4 }
\end{tabular}

Finally, the second course from the Coursera sub-corpus "Lesson Design and Assessment" includes a Welcome week and 6 weeks of lessons with a total of 28 videos. The videos last three hours and twenty-five minutes overall. The transcripts amount to 34,156 words (see Table 4).

Table 4. Lesson Design and Assessment MOOC Course from Coursera

\begin{tabular}{|c|c|c|c|}
\hline \multicolumn{4}{|c|}{ Lesson Design and Assessment } \\
\hline Section & Videos & Duration & \# of words \\
\hline Welcome to the course & 1 video & 00:02:00 & 280 \\
\hline Week 1 & 5 videos & 00:40:00 & 5520 \\
\hline Week 2 & 6 videos & 00:45:00 & 6593 \\
\hline Week 3 & 5 videos & 00:38:00 & 5532 \\
\hline Week 4 & 5 videos & 00:33:00 & 4771 \\
\hline Week 5 & 5 videos & 00:39:00 & 5754 \\
\hline Week 6 & 1 video & 00:08:00 & 1087 \\
\hline Grand totals & 28 videos & $03: 25: 00$ & 29,537 \\
\hline & & Tokens & 34,156 \\
\hline & & Sentences & 1841 \\
\hline
\end{tabular}

Something which is common to the four courses is the fact that these filmed lectures are organised into two separate types of lessons: 1) lessons with one single instructor, or teacher-fronted; and 2) interactions among two or three instructors who deal with a specific topic and present it to the virtual audience. Despite the fact that these filmed lectures are sometimes monologues and other times dialogues, this distinction is not taken into consideration here, since both are treated as types of interactional discourse addressed to an ideal external audience establishing itself as an academic discourse community. What has been analysed so far are the actual transcripts of the filmed lectures, which indicated they were pre-organized and prestructured in terms of quantity of speech, as well as in terms of duration and quality of speech or topics addressed. The instructors' productions in the video recordings are planned and controlled as is always the case in written-to-be-spoken discourse.

Fyle (2013) argues that the parameters of current MOOC design would have to be extended "[i]n order for MOOCs to fulfil the need for social interaction in communities that include teachers, their peers, teacher-educators and mentors. In other words, MOOCs designed for teacher professional development will have to include more sophisticated online forums and other technology-oriented social structures and features that will support effective forms of social-constructivist learning". Furthermore, referring to the continuing professional development of teachers, Fyle highlights that "[s]uccessful teacher professional development requires a social and community-centred approach". Then, quoting Barab et al. (2001), he clarifies that "this approach should foster a culture of sharing and provide sustained support for teachers as they review and reflect on their beliefs and practices".

Leaving aside the technological infrastructures for a moment, the authors of this paper firmly believe that the MOOCs currently being implemented worldwide already allow for "sociability" and interactivity among the members of the community, as long as video lectures are used. They make use of discourse and metadiscursive features that help engage viewers, and foster interest and open dialogue; they also build a certain kind of relationship. This is clearly apparent in this work, as shown by the results of the analysis of the video lectures based on Hyland's categories of metadiscourse. 
Table 5. Hylands's interpersonal model of metadiscourse (2005, p.49)

\begin{tabular}{|c|c|c|}
\hline Category & Function & Examples \\
\hline Interactive & Help to guide the reader through the text & Resources \\
\hline Transitions & express relations between main clauses & in addition; but; thus; and \\
\hline Frame markers & refer to discourse acts, sequences or stages & $\begin{array}{l}\text { finally; to conclude; my } \\
\text { purpose is }\end{array}$ \\
\hline Endophoric markers & $\begin{array}{l}\text { refer to information in other parts of the } \\
\text { text }\end{array}$ & $\begin{array}{l}\text { noted above; see Figure; in } \\
\text { section } 2\end{array}$ \\
\hline Evidentials & refer to information from other texts & according to $\mathrm{X} ; \mathrm{Z}$ states \\
\hline Code glosses & elaborate propositional meanings & $\begin{array}{l}\text { namely; e.g.; such as; in } \\
\text { other words }\end{array}$ \\
\hline Interactional & involve the reader in the text & Resources \\
\hline Hedges & withhold commitment and open dialogue & $\begin{array}{l}\text { might; perhaps; possible; } \\
\text { about }\end{array}$ \\
\hline Boosters & emphasize certainty or close dialogue & $\begin{array}{l}\text { in fact; definitely; it is clear } \\
\text { that }\end{array}$ \\
\hline Attitude markers & express writer's attitude to proposition & $\begin{array}{l}\text { unfortunately; I agree; } \\
\text { surprisingly }\end{array}$ \\
\hline Self mentions & explicit reference to author(s) & I; we; my; me; our \\
\hline Engagement markers & explicitly build relationship with reader & $\begin{array}{l}\text { consider; note; you can see } \\
\text { that }\end{array}$ \\
\hline
\end{tabular}

Table 5 shows Hyland's classification (The interpersonal model of metadiscourse) with the various categories and their functions. Interactive features help to guide the reader through the text and interactional ones involve the reader in the text. A quantitative analysis was carried out using Sketch Engine, a corpus manager and text analysis software (developed by Lexical Computing Limited since 2003). Using this concordance software, the corpus was searched for the items in Hyland's 2005 list of metadiscourse features in academic writing. Then, the concordance lines containing every occurrence of these items were manually checked in order to ensure that they were functioning as metadiscourse; extraneous examples were excluded.

\section{Results and Discussion}

\subsection{The interactive dimension}

All the transition markers listed by Hyland in his Appendix were checked and counted using Sketch Engine. Based on their frequency in the transcripts and on their particular relevance, all the occurrences of the selected items were individually analysed. In detail, they are: also as an addition marker, used to add arguments; but as a means to compare or contrast events; and so and because, which are ways to express consequence relations and draw conclusions. The additive conjunction and, which is very frequently used in all courses, was disregarded at this stage since it is mainly used to link words rather that clauses or sentences.

Table 6. The interactive dimension: Transition markers

\begin{tabular}{|c|c|c|c|c|c|}
\hline \multicolumn{2}{|c|}{$\begin{array}{l}\text { The interactive dimension: } \\
\text { Transition markers }\end{array}$} & TSE & TEO & TSLA & LD\&A \\
\hline \multirow{5}{*}{$\begin{array}{l}\text { Addition: } \\
\text { adding arguments }\end{array}$} & and & 343 & 499 & 837 & 842 \\
\hline & further & 5 & 0 & 0 & 3 \\
\hline & again & 20 & 15 & 22 & 27 \\
\hline & also & 48 & 54 & 46 & 59 \\
\hline & still & 2 & 10 & 28 & 15 \\
\hline \multirow{3}{*}{$\begin{array}{l}\text { Comparison: } \\
\text { comparing and } \\
\text { contrasting events }\end{array}$} & but & 72 & 73 & 57 & 127 \\
\hline & however & 1 & 0 & 15 & 12 \\
\hline & rather & 8 & 3 & 13 & 20 \\
\hline
\end{tabular}




\begin{tabular}{|l|l|c|c|c|c|}
\hline & while & 0 & 7 & 22 & 26 \\
\hline \multirow{2}{*}{$\begin{array}{l}\text { Consequence: } \\
\text { drawing } \\
\text { conclusions }\end{array}$} & so & 150 & 311 & 103 & 151 \\
\cline { 2 - 6 } & since & 2 & 0 & 5 & 5 \\
\cline { 2 - 6 } & of course & 1 & 19 & 11 & 8 \\
\cline { 2 - 6 } & because & 43 & 55 & 28 & 22 \\
\hline
\end{tabular}

Table 6 shows the occurrences of the main transition markers in the four MOOCS. Also as an addition marker links facts or opinions. In Ex. (1) below, the instructor is explaining how she organises group work in class and offers the rationale for her choices. Besides, to reinforce her professional standing position, she adds a further point: "it's also important to assign roles" in the group activity.

Ex. (1)

I try to give very clear instructions. I want all learners to have accountability for their group work. So they have to know that at the end of the activity, there will be some kind of follow-up or wrap-up. I think it's also important to assign roles. (Week 4, TSE, addition marker)

Similarly in Ex. (2), also is used to add arguments to the topic under discussion so as to provide an explanation for the methodological choices proposed to the trainees.

Ex. (2)

Having clear descriptions of the characteristics of a particular category at a particular level makes it easier for me to evaluate students' abilities. Having a clear rubric also helps communicate to students exactly how they'll be evaluated and what is expected of them. (Week 3, LD\&A, adding arguments)

On the contrary, the transition marker but is instead used to compare and contrast facts, events and opinions, as Examples (3) and (4) below show. Specifically, Ex. 3 is an extract from a dialogue between two instructors who are discussing methodological matters about reading skills and related tasks: but, in this case, is used to introduce an interlocutor's different opinion.

Ex. (3)

-But with older learners ...

-Well, I guess with older learners, then, they can probably read at home, can't they? Absolutely. Because they're not so dependent on you. They've got the literacy skills to be able to do that.

-But I think, as you say, it does depend on the type of text and perhaps the task, doesn't it? Yes. (Week 2, TEO, contrasting opinion)

In Ex. (4) below two instructors, in a dialogic form of lecture, are assessing the performance of a teacher shown in a recorded video lecture. One of the instructors uses the transition marker but to contrast and question the teacher's performance and her interlocutor's positive evaluation of it.

Ex. (4)

-Well, it appears that this teacher's assessment is aligned to our objectives. At least from what we can see here. She gave them a list of words and had them find the definitions in the dictionary. Then, she is giving them a task that asks them to recall the spellings and definitions they've learned. And I'm guessing that's really good, right, Jill?

-But, I question the importance of her objectives. (Week 4, LD\&A, contrasting ideas and facts)

What follows are some examples taken from the transcripts in which so is used as a marker to draw conclusions and simultaneously motivate and justify what has just been said and to orientate and encourage inductive reasoning. Instructions are given on how to carry out a particular activity through constructions such as "I want you to..." in Ex. (5), imperatives such as "Make sure" in Ex. (7), and recommendations such as "We recommend that you ..." in Ex. (8). Conclusions and consequences of the requested actions follow in a logical sequence and are introduced by the transition marker so.

Ex. (5)

I want you to predict two things that you might see in that diagram. And in this way I give them a focus, a reason for doing the task that I want them to do. And so there's quite a lot of work to be done, I think, before you actually begin working with the material, the task, or activity. (Week 4, TSE, drawing conclusions)

Ex. (6)

We also try and keep the structure of the tasks as simple as possible, just so it's easier to manage online. (Week 1, TEO, drawing conclusions)

Ex. (7)

Make sure you collect strong student work so that you can use them as templates in future classes. I always keep the best stuff. (Week 3, LD\&A, drawing conclusions)

Ex. (8)

We recommend that you print out and fill in the important information as we explore each one. It will serve as a guide along this journey, so that you can see different approaches in comparison to each other. (Week 1, TSLA, drawing conclusions)

Ex. (9) below shows the use of the adverb because to introduce causality and consequence: the reason why objectives matter is that "we want to get somewhere as teachers", we want to "achieve stuff".

Ex. (9) 
First, objectives for purposes of this module are specific end goals tied to a lesson plan. A target that you, as a teacher, have in mind. And lesson plan objectives matter, because we want to get somewhere as teachers. We're not just saying stuff, we're trying to achieve stuff. (Week 3, LD\&A)

Similarly, in Ex. (10), the transitions marker because introduces the explanation of the methodological principle stated in the previous utterance.

Ex. (10)

In the communicative approach there is a focus on speaking right from the very beginning. Because the purpose of the communicative approach is to help learners communicate in that target language. (Week 5, TSLA)

Zhang \& Sheng (2021, p. 253) have also analysed the use of transition markers and found that they are mainly used to help learners to grasp sentential logic, including the relations of comparison, consequence and addition. They underline that lecturers' tendency to use but and however indicates their inclination to focus on adversative relations in order to highlight key points. They also analysed the use of so, which suggests lecturers' tendency to adopt the inductive method in reasoning and to present evidence before drawing conclusions.

All the transition markers found in the four MOOCs under scrutiny account in particular for one of the three factors which are all deemed to be fundamental in a discourse community, according to Zhang and Sheng (2021). Namely, they enhance intelligibility through the logical organization and flow of discourse while simultaneously providing concepts on teaching methodology and on their application.

\subsection{The Interactional Dimension}

Self-mention markers, which belong to the interactional dimension, account for the other two characteristics of MOOCs and discourse communities, i.e. reliability and interactivity. As explained by Zhang and Sheng (2021), they reveal the presence of the speaker in the text and involve the listeners in the interaction.

As already mentioned, some filmed lectures are monologues and others are dialogues. A high rate of occurrences of the first person singular of the personal pronoun $I$ was found in all the four courses: about 300 occurrences in each course. This means that, despite the fact that discourse is pre-organized and pre-set, the speakers/instructors are personally involved and committed in the discourse and this explains the conversational register of the video lectures. Additionally, instructors use ethos to express their character and emotions in an attempt to persuade the audience, by showing, through their personality, that they are a credible source and worth listening to.

Table 7(a). The interactional dimension: Self mentions

\begin{tabular}{|l|c|c|c|c|}
\hline $\begin{array}{l}\text { The interactional dimension: } \\
\text { Self-mentions }\end{array}$ & TSE & TEO & TSLA & LD\&A \\
\hline$I$ & 292 & 310 & 313 & 346 \\
\hline me & 14 & 30 & 63 & 59 \\
\hline my & 21 & 45 & 54 & 53 \\
\hline we & 98 & 148 & 283 & 298 \\
\hline our & 19 & 9 & 75 & 110 \\
\hline us & 8 & 4 & 31 & 17 \\
\hline
\end{tabular}

The other personal pronoun with statistically meaningful relevance is the first person plural we. The presence of this item was manually coded to identify exclusive and inclusive we. Exclusive we is used to mean the speakers and the instructors but not the listeners; while inclusive we includes the speakers and the audience, who belong to the same teaching and learning community. By using exclusive and inclusive we, speakers project an impression of themselves and explicitly manifest how they stand in relation to their arguments, their community and their listeners, as explained by Hyland (2005, p. 53).

Table 7(b). The interactional dimension: Self mentions

\begin{tabular}{|l|c|c|c|c|}
\hline $\begin{array}{l}\text { The interactional dimension: } \\
\text { Self mentions }\end{array}$ & TSE & TEO & TSLA & LD\&A \\
\hline we & 98 & 148 & 283 & 298 \\
\hline we (exclusive) & 27 & 9 & 67 & 137 \\
\hline we (inclusive) & 71 & 137 & 216 & 161 \\
\hline
\end{tabular}

In Examples (11) and (12) through the use of the exclusive we, as opposed as to "you", the speaker is talking on behalf of both the course institution and of the team of instructors. On the other hand, in Examples (13) and (14), the instructors are including the audience in their discourse, implying that they all belong to the same global community with a common intent and perspective.

Ex. (11) 
In this series of lessons we will take you on a historical journey and show you some of the ways teachers have thought about language, and how they turn these thoughts into actual practice of language instruction in the classroom. (Week 1, TSLA, exclusive we)

Ex. (12)

So again, we are talking about making sure that you have clear objectives, that you have a good reason for doing it. (Week 3, TEO, exclusive we)

Ex. (13)

$\boldsymbol{W} \boldsymbol{e}$ are a global community. We're a global community. And $\boldsymbol{w} \boldsymbol{e}$ 're starting a journey together. (Week 1, TSE, inclusive we)

Ex. (14)

That's exactly right. I'd say we have a perfect objective discussion. We totally do. (Week 2, LD\&A, inclusive we)

Table 8. The interactional dimension: Hedges

\begin{tabular}{|l|c|c|c|c|}
\hline $\begin{array}{l}\text { The interactional dimension: } \\
\text { Hedges }\end{array}$ & TSE & TEO & TSLA & LD\&A \\
\hline I think & 61 & 87 & 5 & 16 \\
\hline can & 93 & 219 & 152 & 180 \\
\hline could & 38 & 32 & 24 & 24 \\
\hline may & 43 & 7 & 43 & 48 \\
\hline might & 39 & 51 & 44 & 52 \\
\hline should & 11 & 11 & 45 & 64 \\
\hline would ('d) & 41 & 80 & 62 & 57 \\
\hline
\end{tabular}

With regard to hedges, all items in Hyland's list were searched and those recurring with greater frequency in the two subcorpora are reported in Table 8. Hedges such as about, quite, sometimes, probably, maybe and perhaps are the adverbs used as hedges which are present with relatively low frequency in the corpus. They are very rarely employed to mitigate the force and the strength of a statement; therefore, due to their low rate of occurrence, they are not worth discussing here.

I think is notably recurrent, especially in the FutureLearn corpus, used by the speakers/instructors to allow information to be presented as a personal opinion rather than a fact, thus opening their position to discussion and negotiation. However, the most frequent hedges appear to be modal verbs; can has the highest number of occurrences. Modality indicates the degree of confidence, prudence and caution in expressing certain areas of knowledge.

Ex. (15)

But I think what you want to avoid is a lot of text, long readings. So you need to display on the interactive whiteboard, don't you? So it needs to be quite short so everyone can see it clearly, and not too much information. (Week 4, TEO)

Ex. (16)

So I think teachers maybe have to work a little bit harder at establishing rapport. (Week 1, TEO)

Ex. (17)

As to monitoring your students' progress, I think you should never underestimate the power of justified praise. I think power of praise is something extremely important, and it helps to keep students motivated. (Week 4, TSE)

Examples (15), (16) and (17) show the use of the phrase I think through which the position of the speaker is presented as an opinion leaving room for discussion. In particular, in Ex. (15), the hedge I think is used by the instructor to weaken the strong statement which follows, where the verbs "you want" and "you need" are used to propose a methodological procedure. Similarly, in Ex. (17), thanks to her expertise and authority in the field of teaching, the instructor introduces her ideas on praising students through the hedge $I$ think; the first time, to mitigate the strong following statement "you should never underestimate the power of justified praise". The second time, she uses I think to introduce a general rule of which she highlights the importance with her lexical choices, by defining the power of praising students as being "extremely important". On the contrary, in Ex. (16), the hedge I think is followed by another hedge, i.e. maybe to underline and reinforce caution in the speaker's position.

Examples (18) and (19) below, which come from the Coursera MOOCs, show the use of can. In this sub-corpus this modal verb is very frequently used to establish a link with the audience, addressing the interlocutors in a colloquial manner. Can is much more frequently preferred than the more formal could.

Ex. (18)

And I guess you can say that our greatest hope in giving you this third course is that you can learn from both of us, both the good and the bad, so you can truly be not just smart, but super smart. (Welcome Week 4, LD\&A)

Ex. (19)

Can you guess what question word we ask when we think about content? (Week 1, TSLA) 
We also looked at other modal verbs such as may, might, should and would, albeit only quantitatively; their total number of occurrences is shown in Table 8. At this stage, the authors will not provide a thorough discussion of them. As a matter of fact, any analysis of these modals would entail a more detailed qualitative investigation of the concordance lines in Sketch Engine in order to ascertain whether the modals function as metadiscursive features or if they carry propositional meaning in the specific context used. Modal verbs and their character merit a discussion of their own, and therefore can be considered for further research.

Table 9(a). The interactional dimension: Engagement markers

\begin{tabular}{|c|c|c|c|c|}
\hline $\begin{array}{c}\text { The interactional dimension: } \\
\text { Engagement markers }\end{array}$ & TSE & TEO & TSLA & LD\&A \\
\hline you & 221 & 737 & 485 & 702 \\
\hline your & 36 & 104 & 106 & 250 \\
\hline Let's & 1 & 15 & 6 & 16 \\
\hline Let me & 0 & 5 & 11 & 14 \\
\hline think about & 1 & 2 & 1 & 5 \\
\hline
\end{tabular}

As for the category of engagement markers, they explicitly address the listeners, either to focus their attention or include them as discourse participants. They are used to highlight or downplay the presence of the listeners in the texts. According to Zhang and Sheng (2021, p. 254), "[f]or lecturers, the main purpose of adopting engagement markers is perhaps to construct affiliation in invisible interaction with learners in MOOCs".

As Table 9(a) shows, the listeners are involved in all the courses through the use of the pronoun you. The second person singular and plural of the personal pronoun you, as well as the second person singular and plural of the possessive adjective your, tend to be used by instructors to orientate listeners to the discourse and focus their attention on the topic at stake, by directly involving them. Furthermore, very few occurrences of the imperative form Let's were found. Besides, think about is present in every course under scrutiny, although with few occurrences. This expression highlights the importance of the direct involvement of the audience and the immediacy and interactivity of the filmed lectures, based on the "principle that language use always draws on, and creates for itself, a social and communicative dimension" (Hyland 2015, p. 8). Consider Examples (20), (21), (22) and (23) below.

Ex. (20)

Let's move on to the category of content. (Week 1, TSLA)

Ex. (21)

Let's watch, and please pay attention to this small list of ideas and see if our teachers follow through with each one. Remember, clearly state the instructional objectives, check for understanding, establish specifics, and discuss the importance of the objective. (Week 5, LD\&A)

Ex. (22)

Think about what parts of the lesson might be particularly difficult, and think of what questions and challenges students might have as you're presenting. (Week 3, LD\&A)

Ex. (23)

Before we get to that, however, let me just remind you of some key concepts we've covered in the first three lessons in this module. (Week 5, LD\&A)

In spite of the fact that $O K$ is not included in the metadiscoursal items listed in Hyland's 2005 Appendix, in the opinion of the authors, this feature can be included in the category of_engagement markers. 


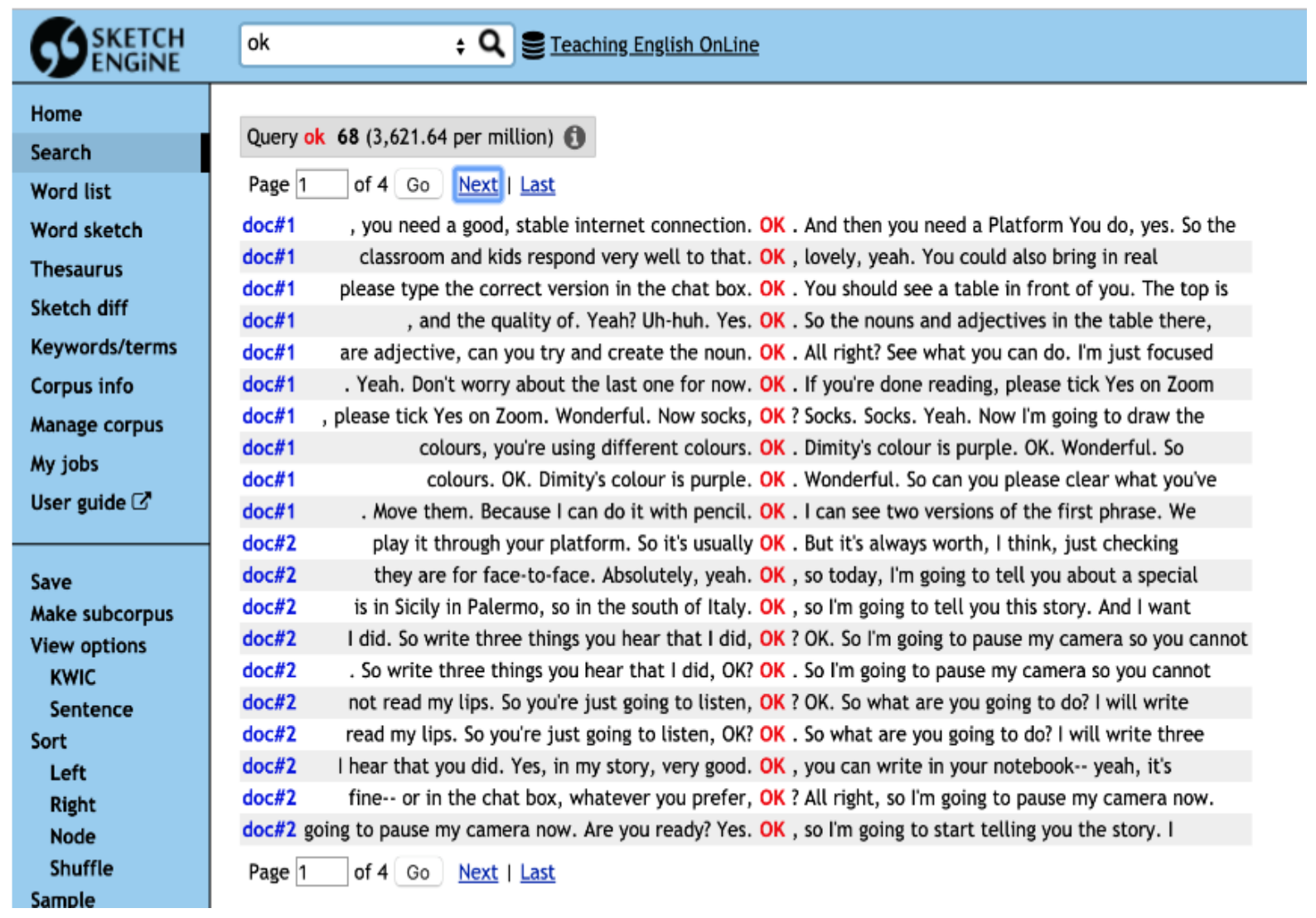

\section{Figure 1. Occurrences of $\mathrm{OK}$}

Ok, Yeah and Yes, are commonly used in spoken discourse, and in the filmed lectures, they reinforce the idea that any real-life utterance communicates information as well as emotions, values and relationships (Hyland 2015, p. 7). Several occurrences of OK were found in both courses in the FutureLearn corpus, especially in the course Teaching English Online, as some of the concordance lines in Figure 1 show. The expressions "OK, lovely, yeah.", "OK. All right?", "Ok Wonderful.", OK, so I'm going to start telling you the story," 1) check listeners' involvement and comprehension and 2) signal the speakers' engagement in the interaction.

Table 9(b). The interactional dimension: Engagement markers

\begin{tabular}{|l|c|c|c|c|}
\hline $\begin{array}{l}\text { The interactional dimension: } \\
\text { Engagement markers }\end{array}$ & TSE & TEO & TSLA & LD\&A \\
\hline OK & 25 & 68 & 0 & 0 \\
\hline Yeah & 5 & 99 & 5 & 8 \\
\hline Yes & 11 & 50 & 7 & 46 \\
\hline
\end{tabular}

Although $O k$ was not found in the Coursera corpus, Yeah and Yes, which were also included in the category of engagement markers, were found in all the courses, albeit with higher frequency again in the Teaching English Online course by FutureLearn. The difference in frequency of use of these items is possibly due to the higher presence of dialogues between different instructors in the video recordings, marking a higher degree of spontaneity or informality, typical of spoken discourse.

The last feature which we take into consideration is the booster really, used to emphasize certainty about a proposition or confidence in an assertion, to express commitment to a proposition or to close off alternative viewpoints by strengthening the position of the speaker (see Carrió-Pastor \& Muñiz Calderón 2015, p. 221). Really is used very frequently in all four MOOCs under scrutiny, as shown in Table 10.

Table 10. The interactional dimension: Boosters

\begin{tabular}{|l|c|c|c|c|}
\hline $\begin{array}{l}\text { The interactional dimension: } \\
\text { Boosters }\end{array}$ & TSE & TEO & TSLA & LD\&A \\
\hline really & 23 & 93 & 35 & 34 \\
\hline
\end{tabular}


Ex. (24)

So that's another thing to think about is how you get people to form relationships where they feel safe and confident speaking to the other people in their group. And that rapport, building that rapport is probably the most essential thing you really need to work on when you're starting out with an online class. The key skills I would say you need to have are really, really bringing a lot of energy to every single class. So I always thought I had a really good rapport with my students, and that I was always a really friendly person. But sometimes after giving these classes, my face almost hurts from smiling so much and from using so many different expressions with the students. But it's really, really necessary. (Week 1, TEO)

4.3. Metaphors on Discourse Community

All the metadiscursive features found in the two sub-corpora FutureLearn and Coursera concur to create a persuasive and engaging learning environment characterised by a colloquial and informal register and style. Along with the metadiscursive features, the listeners are also engaged and involved through the use of the metaphors of community and of a journey to be taken together. As can be noticed from the examples below, from (25) to (37), three of the courses in the corpus utilize the metaphor of a community starting a journey together, taking steps, and going on a learning adventure. The online community is engaging in a great trip or embarking on a journey through time thanks to a time machine.

Ex. (25)

We're a global community. And we're starting a journey together. (TSE)

Ex. (26)

This week our first stop is getting learners ready to learn...(TSE)

Ex. (27)

Back to our first stop, getting learners ready to learn... (TSE)

Ex. (28)

The second stop of our journey was reviewing learning ... (TSE)

Ex. (29)

The last stop in our journey this week is engaging with learners (TSE)

Ex. (30)

This is a journey in which we are embarking (TSE)

Ex. (31)

And enjoy the ride! (TSE)

Ex. (32)

I think this online community thing is an important thing. (TEO)

Ex. (33)

Join an online community is another important thing. (TEO)

Ex. (34)

We are going to take you through the course over the next four weeks (TEO)

Ex. (35)

Buckle up, it should be a great trip! (TSLA)

Ex. (36)

In the next video, we will discuss precisely how we are going to take you on this journey through time. A time machine, you say? (TSLA)

Ex. (37)

Climb aboard. Let's go on an adventure together. (TSLA)

Metaphors of the community were not found in the MOOC Lesson Design and Assessment (LD\&A) by Coursera. However, the presence of the adverb together was looked at, since a significant number of occurrences resulted from the quantitative search, as can be seen in Figure 2. Together is used to invite discussion and involve the audience to participate in the activities. As is the case with students in class, teachers online are similarly encouraged to work together to accomplish a task and this accounts for the interactivity, partaking and sharing typical of MOOC courses and of learning communities. 


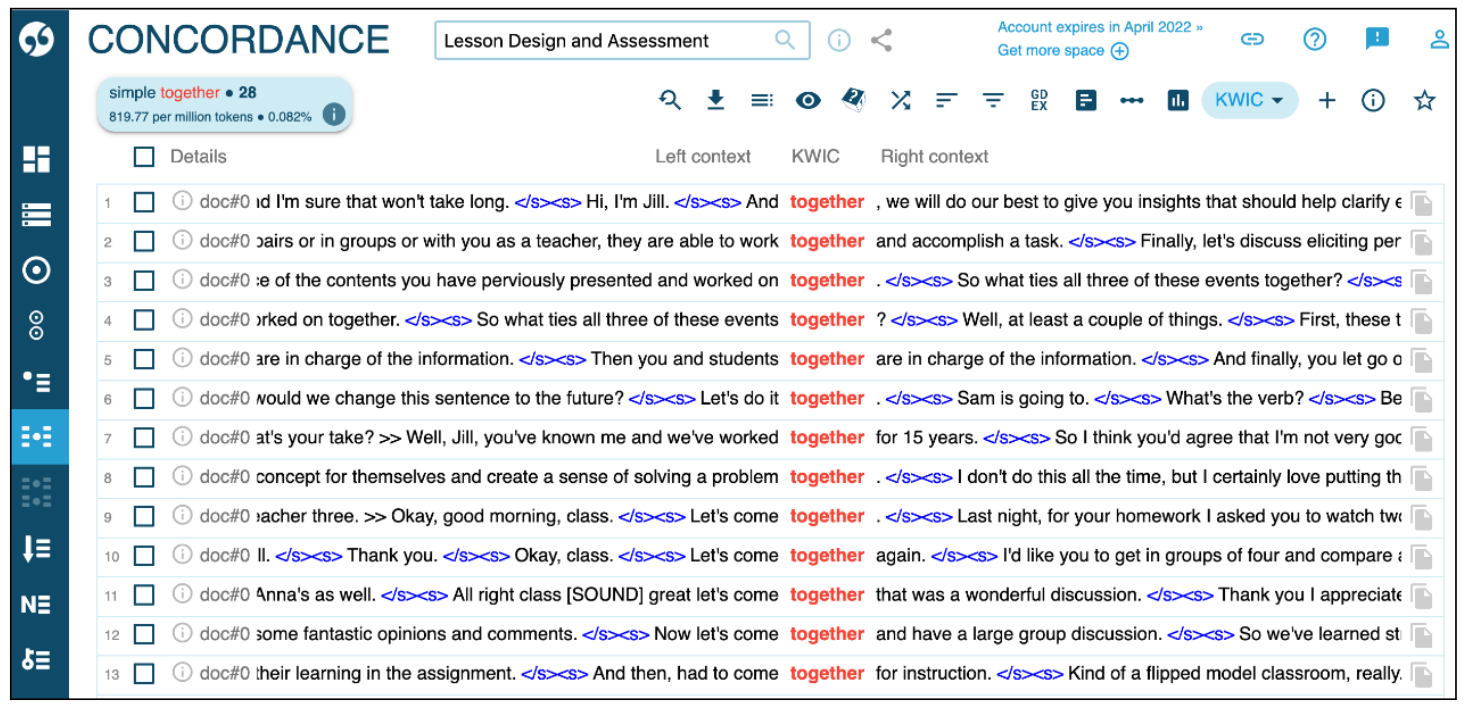

Figure 2. Together in Lesson Design and Assessment MOOC Course

\section{Conclusions}

This study has examined the use of metadiscourse in four teacher training MOOCs. The objective of the research was to find out whether the course instructors make use of metadiscourse in the spoken production of the video lectures to orientate their listeners. Analysis of the transcripts of the filmed lectures enabled us to find many of the metadiscourse markers used in written discourse. In particular, a quantitative analysis revealed a higher presence of interactional features such as self mentions, engagement markers, hedges and boosters, rather than interactive features. These commentaries are not just ornamentation, or fillers, but rather signal the speakers' attitudes towards the texts and their listeners. In other words, they bring the material alive by persuasively reinforcing the speakers' attitudes and stance, and in so doing they perform a rhetorical function. Besides, they present information in ways which engage the participants as members of a discourse community, in spite of the fact that MOOCs are meant to be asynchronous. The factors of reliability, intelligibility and interactivity should increasingly be considered and promoted in MOOC lectures, by utilizing different categories of metadiscourse.

\section{References}

Ädel, A. (2006). Metadiscourse in L1 and L2 English. Amsterdam/Philadelphia: John Benjamins Pbl. Company.

Ädel, A. (2010). Just to give you kind of a map of where we are going: A Taxonomy of Metadiscourse in Spoken and Written Academic English. Nordic Journal of English Studies 9(2), 69-97.

Ädel, A. (2012). 'What I want you to remember is...': Audience orientation in monologic academic discourse. English Text Construction 5(1), 101-127.

Barab, S. A, Makinster, J. G, Moore, J. A., \& Cunningham, D. J. (2001). Designing and building an on-line community: The struggle to support sociability in the inquiry learning forum. Educational Technology Research and Development 49(4), 71-96.

Bernard-Mechó, E. (2015), A multimodal discourse analysis of linking metadiscursive elements in two opencourseware lectures (MOOCs), Procedia, Social and Behavioural Sciences 212, 61-66.

Borg, E. (2003). Key concepts in ELT. Discourse community, ELT Journal, 57(4), 398-400.

Carrió-Pastor, M. L., \& Muñiz Calderón, R. (2015). A contrastive analysis of metadiscourse features in business e-mails written by non-native speakers of English. Procedia, Social and Behavioral Sciences 173, 214-221.

Crismore, A. (1989). Talking with readers. Metadiscourse as rhetorical act. New York: Peter Lang.

Crismore, A., Markkanen, R. \& Steffensen, M. S. (1993). Metadiscourse in persuasive writing. A study of texts written by American and Finnish university students. Written Communication 10, 39-71.

Fyle, C. O. (2013) Teacher education MOOCs for developing world contexts: Issues and design considerations, sixth international conference of MIT's Learning International Networks Consortium (LINC) at Cambridge, Massachusetts, USA, June 2013.

Giordano, M. \& Marongiu M.A. (2020). And as I said at the beginning, this is a journey in which we are embarking: Metadiscourse as rhetorical strategy in online teaching methodology courses. In S. Consonni, L. D'Angelo, \& P. Anesa, eds.) Digital Communication and Metadiscourse. Changing Perspectives in Academic Genres (pp. 131-161). Bergamo: CELSB Libreria Universitaria. 
Hyland, K. (1998a). Persuasion and Context: The Pragmatics of Academic Metadiscourse. Journal of Pragmatics 30, 437455.

Hyland, K. (1998b). Exploring corporate rhetoric: Metadiscourse in the CEO's letter. Journal of Business Communication $35(2), 224-245$.

Hyland, K. (2000). Disciplinary Discourses: Social Interactions in Academic Writing. London: Longman.

Hyland, K. (2005). Metadiscourse. Exploring interaction in writing. London-New York: Continuum.

Hyland, K. (2015). Metadiscourse. In Tracy, K. (ed.), The International Encyclopedia of Language and Social Interaction (pp. 1-11). Oxford: Wiley-Blackwell.

Hyland, K. (2017). Metadiscourse: What is it and where is it going? Journal of Pragmatics, 113, 16-29.

Hyland, K., \& Feng, K. J. (2018). "In this paper we suggest": Changing patterns of disciplinary. metadiscourse. English for Specific Purposes, 51, 18-30.

Hyland, K., \& Tse, P. (2004). Metadiscourse in academic writing: A reappraisal. Applied Linguistics 25(2), 156-177.

Kim, D., \& Vorobel, O. (2015). Discourse communities: From origins to social media. Discourse and Education, Encyclopedia of Language and Education.

Lave, J., \& Wenger, E. (1991). Situated Learning. Legitimate Peripheral Participation. Cambridge, UK: Cambridge University Press.

Mauranen, A. (1993). Contrastive ESP rhetoric: Metatext in Finnish-English economic texts. English for Specific Purposes $12,3-22$.

Pouezevara, S. R., \& Horn, L. J. (2016). MOOCs and Online Education: Exploring the Potential for International Educational Development. RTI Press Publication No. OP-0029-1603. Research Triangle Park, NC: RTI Press, 1-11. http://dx.doi.org/10.3768/ rtipress.2016.op.0029.1603

Ryoo, M.-L. (2005). Metadiscourse in computer-mediated communication in a culturally diverse group. Discourse and Cognition 12(1), 21-41.

Singh, G., \& Chauhan, R. (2017). Awareness towards Massive Open Online Courses (MOOCs) and their usage for Teacher Education in India. Asian Journal of Distance Education, 12(2), 81-88.

Swales, J. M. (1990). Genre Analysis: English in Academic and Research Settings. Cambridge: Cambridge University Press.

Vande Kopple, W. J. (1985). Some exploratory discourse on metadiscourse. College Composition and Communication, 36(1), 82-93.

Zhang, D., \& Sheng, D. (2021). EFL lecturers' metadiscourse in Chinese university MOOCs across course types. Corpus Pragmatics 5, 243-270.

\section{Endnotes}

\footnotetext{
${ }^{1}$ Though this paper has been jointly conceived, organised and developed, Michela Giordano is responsible for Sections 2.2, 3, 4.1, 4.3 and 5; Maria Antonietta Marongiu is responsible for Sections 1, 2.1, 4.2. The general plan and editing are a shared effort.
} 